\title{
KONSEP DIRI ARTIS STREET ART DALAM MENGHASILKAN MURAL KRITIK SOSIAL DI JAKARTA
}

\author{
Masnah $^{1}$ \\ ${ }^{1}$ Program Studi Ilmu Komunikasi, Universitas Nasional \\ email :masnahfadholi@gmail.com
}

Korespondensi : masnahfadholi@gmail.com

\begin{abstract}
Absract
This study aims to determine the self-concept of street art artists in producing murals in Jakarta. This self-concept is researched through the knowledge, expectations and judgment of street art mural artists in producing a mural of social criticism.This study uses a qualitative approach with one person informant. Data obtained using in-depth interviews, observation, documentation of literature studies, internet searching. The data analysis techniques used are data reduction, data collection, data presentation, drawing conclusions, and evaluations. The results of the study describe that, the knowledge of street art artists possessed in addition to technical knowledge of murals in producing mural works of social criticism. The hope of street art artists in producing mural works of social criticism. the most important thing is self-satisfaction and subsequent achievement to get an appreciation or award. street art artist. have an assessment in maintaining the values and authenticity of their respective works. In conclusion, the self-concept of street art artists in producing social critique murals is that street art artists are honest in their work, have strong mentality, try to be cooperative in their work, have high expectations on their work, have high learning motivation, are communicative, like systematic patterns of work and are a bit perfectionist.
\end{abstract}

Keywords: self concept,mural,social criticism, artist, jakarta

\begin{abstract}
Abstrak
Penelitian ini bertujuan untuk mengetahui konsep diri artis street art dalam menghasilkan mural di Jakarta. Konsep diri ini diteliti melalui pengetahuan, harapan dan penilaian artis street art mural dalam menghasilkan mural kritik sosial. Penelitian ini menggunakan pendekatan kualitatif dengan informan satu orang. Data diperoleh dengan menggunakan wawancara mendalam, observasi, dokumentasi studi literatur, internet searching. Adapun teknik analisis data yang digunakan adalah reduksi data, pengumpulan data, penyajian data, penarikan kesimpulan, dan evaluasi. Hasil penelitian mendeskripsikan bahwa, pengetahuan artis street art yang dimiliki selain pengetahuan teknis mural dalam menghasilkan karya mural kritik sosial. Harapan artis street art dalam menghasilkan karya mural kritik sosial. yang paling utama adalah kepuasan diri dan pencapaian selanjutnya mendapatkan apresiasi atau penghargaan. Artis street art memiliki penilaian dalam menjaga nilai-nilai dan keaslian karyanya masing-masing. Kesimpulan, konsep diri artis street art dalam menghasilkan mural kritik sosial yaitu artis street art jujur dalam berkarya, bermental kuat, berusaha kooperatif
\end{abstract}


dalam bekerja, berekspektasi tinggi pada karyanya, motivasi belajar yang tinggi, komunikatif, menyukai pola sistematis dalam bekerja dan sedikit perfeksionis.

Kata kunci: konsep diri, mural, kritik social, artis, jakarta

\section{PENDAHULUAN}

\section{Latar Belakang Masalah}

Manusia adalah salah satu mahluk yang diberi oleh Tuhan, akal budi dan seperangkat naluri. Naluri ingin tahu, sosial, berkomunikasi dan naluri ingin memperoleh kebahagiaan. Inilah yang membedakan manusia dengan mahluk lain ciptaan Tuhan.

Manusia diciptakan Tuhan dengan banyak perbedaan mulai dari pemikiran, persepsi, pola pikir, bahasa, ras, warna kulit, ajaran, pendidikan, ekonomi, tingkat sosial, pengetahuan dan pengalaman. Sehingga setiap manusia bisa mengetahui segala kekurangan dan kelebihan pada diri kita. Perbedaan pengalaman membentuk individu menjadi lebih baik sesuai dengan harapan individu tersebut.

Tumbuh dan berkembangnya manusia sebagai individu sudah menjadi ciri khasnya, mereka belajar dari kehidupan serta lingkungan sekitarnya. Sejarah mahluk hidup dari masa lalu dapat membuat dirinya memandang diri lebih baik atau lebih buruk dari kenyataan sebenarnya (Centi, 1993).

Cara pandang individu terhadap dirinya akan membentuk suatu konsep tentang diri sendiri. Konsep tentang diri merupakan hal yang penting bagi kehidupan individu, karena konsep diri menentukan bagaimana individu bertindak dalam berbagai situasi (Calhoun \& Acocella, 1990).

Konsep diri juga dianggap sebagai pemegang peranan kunci dalam pengintegrasian kepribadian individu, di dalam memotivasi tingkah laku serta di dalam pencapaian kesehatan mental (Burns, 1993).

Dalam bertindak individu memiliki pengharapan mengenai dirinya sendiri. Apabila ia berpikir bisa meraih sesuatu dan akhirnya sukses, maka dapatlah ia, maka sukseslah ia. Begitu pula sebaliknya, apabila individu tersebut berpikir gagal dan tidak bisa mendapatkan sesuatu hal, maka ia tidak mungkin mendapatkan apa yang ia mau dan iapun gagal, yang sebenarnya dirinya telah menyiapkan diri untuk gagal. Bisa dikatakan bahwa konsep diri merupakan bagian diri yang mempengaruhi setiap aspek pengalaman baik itu pikiran, perasaan, persepsi, dan tingkah laku individu (Calhoum \& Acocella, 1990).

Berkembangnya manusia merupakan proses yang alami, hingga terbentuknya konsep diri yang tidak secara instan, melainkan dengan proses belajar sepanjang hidup manusia. Konsep diri berasal dan berkembang sejalan pertumbuhannya, terutama akibat dari hubungan individu dengan individu lainnya (Centi, 1993).

Ketika individu lahir, individu jelas tidak memiliki pengetahuan tentang dirinya sama sekali, tidak memiliki harapan-harapan yang ingin dicapainya serta tidak memiliki penilaian terhadap diri sendiri (Calhoun \& Acocella, 1990).

Namun seiring dengan berjalannya waktu individu mulai bisa membedakan antara dirinya, orang lain dan benda-benda di sekitarnya dan pada akhirnya individu 
mulai mengetahui siapa dirinya, apa yang diinginkan serta dapat melakukan penilaian terhadap dirinya sendiri (Calhoun \& Acocella, 1990).

Apapun yang kita lakukan akan membentuk konsep diri. Konsep diri akan menentukan bagaimana kita melakukan sesuatu sesuai dengan yang kita harapkan. Apapun pekerjaan kita. Konsep diri menyatu dengan kepribadian serta memotivasi tindakan kita. Dan ini akan terlihat ketika kita melakukan pekerjaan tertentu. Dalam bekerja kita akan memperlihatkan bagaimana pengalaman, kemauan keras hingga ketahanan mental akan tekanan terhadap pekerjaan.

Apakah profesi kita, baik itu dosen, mahasiswa, pedagang sayur, dan loper koran. Apakah kita sudah benar-benar kita resapi. Tentu jawabannya bisa berbedabeda, ada yang menjawab tidak sama sekali, belum tentu dan ya.

Dalam kita melakukan apa yang menjadi profesi, kita seharusnya tidak bimbang dalam menjalankannya. Kita sebagai mahluk sosial, tentu apa yang kita lakukan akan menimbulkan dampak baik secara langsung atau tidak tidak akan langsung akan mempunyai pengaruh bagi lingkungan di sekitar kita.

Salah satu profesi yang penulis teliti yaitu pelukis jalanan (street art). Dan street art ini berhubungan dengan komunikasi visual. Komunikasi visual adalah suatu usaha dalam menyampaikan pesan lewat tampilan gambar atau grafik. Pesan ini biasanya berupa tanda atau makna tertentu yang digunakan agar sasarannya dapat merespon pesan yang disampaikan. Bentuk komunikasi ini termasuk dalam komunikasi satu arah karena penerima pesan tidak dapat berinteraksi secara langsung kepada penyampai pesannya.

Dalam pengertian modern, desain komunikasi visual menurut Widagdo (1993) adalah "desain yang dihasilkan dari rasionalitas, dilandasi pengetahuan, bersifat rasional dan pragmatis" (Sumbo Tinarbuko, 2000). Hal ini dipercaya mampu memberikan ilustrasi atau mengajak orang yang melihatnya memberikan respon yang ditampilkan oleh tampilan visualisasi tersebut.

Oleh karena itu, para desainer yang merancang komunikasi visual tersebut harus mampu membangkitkan jiwa orang yang melihatnya. Tugas desain komunikasi visual adalah mengidentifikasi hingga akhirnya memilih dan memutuskan simbol atau tanda yang sesuai dengan konteksnya. Sebuah produk dalam desain komunikasi visual dalam wujud apapun pada dasarnya adalah sebuah jawaban atas persoalan komunikasi yang dihadapi (FSR ISI, 2009). Selain itu, komunikasi visual juga harus memiliki konsep, agar pesan yang disampaikan efektif kepada sasarannya.

Desain komunikasi visual merupakan representasi sosial budaya masyarakat dan salah satu manifestasi kebudayaan yang berwujud produk dari nilai-nilai yang berlaku pada waktu tertentu (Sumbo Tinarbuko, 2000). Komunikasi visual, saat ini terdapat diberbagai bidang kehidupan manusia, hal yang umum salah satunya terdapat dalam ruang publik atau tempat-tempat umum terbuka yang dapat dilihat oleh banyak orang. Komunikasi visual yang ditampilkan disini merupakan karyakarya dari para seniman jalanan atau seni visual, yang sering dikenal dengan sebutan street art.

Street art merupakan sebuah seni, khususnya seni visual yang biasanya di aplikasikan di ruang publik, seperti tembok, halte, jembatan penyeberangan, tempat- 
tempat transit, dan juga terdapat di angkutan-angkutan umum. Karya street art bukanlah sebuah vandalisme semata, namun terdapat pesan yang bermakna didalamnya, karena street art merupakan sebuah pengungkapan ekspresi atau pencurahan seseorang ataupun kelompok ke dalam ruang publik. Seniman street art dalam membuat karyanya dilandasi oleh sesuatu yang dilihatnya secara umum, seperti fenomena sosial atau peristiwa-peristiwa yang menyinggung masalah negara. Kebanyakan street art menyampaikan pesan berupa kirtik sosial yang dirasakan oleh pembuatnya atau oleh masyarakat umum. Kegiatan semacam ini dapat juga dikatakan sebuah aksi nyata yang dilakukan oleh para pembuat street art untuk menyampaikan aspirasinya melalui sebuah karya seni.

Dalam karya street art terdapat beberapa jenis karya yang dapat dikelompokkan, diantaranya yaitu, Mural, Grafity, Stencil, Wheatpaste, Tagging, Poster Art, dan Stiker Art. Namun dalam penulisan ini lebih memfokuskan terhadap karya street art yang berupa jenis mural. Karena jenis mural sering terdapat di ruangruang publik dibandingkan dengan yang lain, dan termasuk karya yang unik karena memiliki persyaratan yang harus dipenuhi, yaitu keterkaitannya dengan arsitektur atau bangunan, baik dari segi desain, usia, perawatan, dan segi kenyamanan pengamatannya.

Mural adalah cara melukis atau menggambar di atas media dinding, tembok, atau permukaan halus yang bersifat permanen lainnya. Karya mural lebih bebas dalam cara pembuatannya, yang dapat menggunakan cat tembok, cat kayu, bahkan pewarna apapun juga seperti kapur tulis atau alat yang dapat menghasilkan gambar. Mural memberikan definisi sebagai lukisan besar yang dibuat untuk mendukung ruang arsitektur. Definisi tersebut bila diterjemahkan lebih lanjut, maka mural sebenarnya tidak bisa dilepaskan dari bangunan dalam hal ini dinding. Dinding dipandang tidak hanya sebagai pembatas ruang maupun sekedar unsur yang harus ada dalam bangunan rumah atau gedung, namun dinding juga dipandang sebagai medium untuk memperindah ruangan (dechantq.wordpress.com).

Karya-karya street art bisa menjadi sarana yang kuat bagi publik dengan banyak menyinggung tema tentang kritikan. Beberapa artis street art membuat karyanya dengan efek yang mencolok untuk mendapatkan perhatian masyarakat tentang kasus politik di Jakarta. Ada yang melihat ruang publik untuk mengekspresikan karya pribadi mereka, tetapi sebagian artis lainnya cukup menghargai tentang makna dari street art yang penuh dengan tantangan dan resiko. Karya street art yang juga merupakan bentuk aksi dalam menyampaikan aspirasi dan sikapnya atas fenomena sosial, dapat membantu merubah atau membentuk opini setiap orang yang melihatnya. Karena karya street art biasanya selalu menyinggung tentang kritik sosial agar masyarakat dapat menentukan sikap dan tindakan dalam memandang fenomena dan dinamika di dalam masyarakat sosial.

Kehadiran kritik sosial ditandai dengan adanya kejadian dan fenomena sosial yang dianggap tidak masuk akal dan tidak rasional, sehingga menimbulkan pemikiran yang kritis dan logis untuk melihat kejadian dan fenomena tersebut.

Kritik adalah kecaman atau tanggapan, kadang-kadang disertai uraian dan pertimbangan baik atau buruk terhadap sesuatu hal. Sedangkan sosial adalah hal yang berkenaan dengan masyarakat. Menurut Astrit Susanto "kritik sosial adalah 
penilaian ilmiah ataupun pengujian terhadap situasi masyarakat pada suatu saat" (Amin Rais,1986). Masyarakat dalam situasi dan kondisi tertentu dapat dikaji melalui penilaian dan pengujian yang bersifat ilmiah dapat menghasilkan suatu pandangan tertentu bagi orang yang mengkajinya. Biasanya pengkajian ini dalam situasi dan kondisi yang dirasa memprihatinkan bagi beberapa orang ataupun bagian dari masyarakat. Kritik sosial dinilai sebagai barometer sosial politik suatu masyarakat. Adanya pendapat-pendapat yang menginginkan koreksi, perbaikan dalam masyarakat menjelaskan adanya perubahan. (Amin Rais,1986).

Kritik sosial hadir atas dasar keinginan untuk suatu perubahan sosial politik yang menyangkut norma-norma dan aturan yang berkembang di kalangan masyarakat yang ditunjukkan untuk suatu negara, kelompok besar, ataupun kelompok kecil.

Jakarta dan sekitarnya dapat diketahui beberapa komunitas dan street artis yang sudah menghasilkan karya-karyanya di jalan, di antaranya adalah Gardu House, Artcoholic, Serrum, Monsta Jam, Kabin, Propagraphic Movement, Garis Keras feat Spik Lala, Jungle Boxs, Laskar Artup, SSST (super secret street team), Tas Tas, Duo Coblon, Kampung Segart, Kompeni, Milisi Mural Depok, Andi Rharharha, The Popo, Robowobo, Hello Guno, Jah Ipul, Arman, dan masih banyak komunitas street art lain yang selalu menyampaikan pesan sindiran atau kritik sosialnya di jalan.

Namun dalam penelitian ini, penulis memfokuskan penelitian terhadap karya mural dari salah satu komunitas street art Jakarta, yaitu Garis Keras feat Spik Lala. Karena karya-karya dari komunitas tersebut lebih berani menampilkan sifat pesan sindiran atau kritik yang keras dan tajam terhadap fenomena sosial saat ini ataupun yang akan datang. Mural yang dibuatnya berdasarkan fakta dan kenyataan yang dilihat di lapangan, sebagai bentuk kritik sosial. Garis Keras feat Spik Lala terkadang tidak hanya memberikan pesan yang bersifat sindiran dan kritik saja, namun terdapat juga pesan yang bersifat informasi dan himbauan sebagai pesan remind kepada masyarakat.

Salah satu contoh karya street art Garis Keras feat Spik Lala adalah gambar yang menampilkan beberapa orang dalam suatu kelompok yang sedang berdiskusi. Seperti layaknya pejabat-pejabat umum lainnya yang memakai jas dan berdasi, sedang mendiskusikan suatu hal dengan dilengkapi oleh laptop, handphone, rokok, dan buah-buahan. Namun hal yang uniknya adalah, kepala-kepala orang tersebut beraneka ragam, ada yang berjenis binatang, monster, bahkan ada juga yang berbentuk karungan uang dan ada juga yang tidak memiliki kepala. Visualisasi tersebut dilengkapi oleh tulisan atau kalimat tanda tanya, yaitu "Insting Lo Bilang Apa?", serta terdapat pesan himbauan yang bertuliskan "Hati-Hati Dalam Memilih".

Dari wacana di atas peneliti menarik permasalahan tentang konsep diri Artis Street Art dalam Menghasilkan Mural "Kritik Sosial" di Jakarta.

Di mana dalam menghasilkan artis Street Art memiki konsep diri yang mempengaruhi sikap muralnya. Pembahasan tentang konsep diri artis Street Art, penulis anggap menarik untuk diteliti, karya mural merupakan bagian dari media komunikasi di mana selama ini masyarakat selalu melihat aktifitas mural hanya 
cenderung pada hasil muralnya saja. Akan tetapi, di balik hasil mural tersebut terdapat diri artis Street Art yang dengan konsep dirinya masing-masing.

\section{Permasalahan}

Adapun fokus pertanyaaan penelitian ini adalah sebagai berikut :

1. Bagaimana Pengetahuan Artis Street Art dalam Menghasilkan Mural "Kritik Sosial" di Jakarta?

2. Bagaimana Harapan Artis Street Art dalam Menghasilkan Mural "Kritik Sosial" di Jakarta?

3. Bagaimana Penilaian Artis Street Art dalam Menghasilkan Mural "Kritik Sosial" di Jakarta?

4. Bagaimana Konsep Diri Artis Street Art dalam Menghasilkan Mural "Kritik Sosial" di Jakarta?

\section{KERANGKA TEORITIS}

Kerangka teoritis dalam penelitian ini adalah konsep diri. Konsep diri adalah cara pandang individu terhadap dirinya akan membentuk suatu konsep tentang diri sendiri. Konsep tentang diri merupakan hal yang sangat penting bagi kehidupan individu, karena konsep diri menetukan bagaimana individu bertindak dalam berbagai situasi (Rola, 2006).

Pengharapan mengenai diri akan menetukan bagaimana individu akan bertindak dalam hidup. Dapat dikatakan bahwa konsep diri merupakan bagian diri yang mempengaruhi setiap aspek pengalaman, baik itu pikiran, perasaan, persepsi dan tingkah laku individu. Singkatnya konsep diri diartikan sebagai gambaran mental individu yang terdiri dari pengetahuan tentang diri sendiri, pengharapan bagi diri sendiri, dan penilaian terhadap diri sendiri (Calhoun dan Acocella, 1990).

Konsep diri merupakan sebuah gambaran mental individu yang terdiri dari pengetahuan diri sendiri, pengharapan bagi diri sendiri dan penilaian terhadap diri sendiri (Centi, 1993). Kemudian Hurlock (1990) mengatakan bahwa konsep diri adalah gagasan tentang diri sendiri yang berisikan mengenai bagaimana individu melihat dirinya sendiri sebagai pribadi, bagaimana individu merasa mengetahui tentang dirinya sendiri, dan bagaimana individu menginginkan diri sendiri menjadi manusia sebagaimana yang diharapkan.

\section{Aspek-Aspek Pembentuk Konsep Diri}

Calhoun dan Acocella (1990) menjelaskan bahwa konsep diri merupakan gambaran mental yang dimiliki oleh seorang individu. Gambaran mental yang dimiliki oleh individu memiliki tiga aspek, yaitu aspek pengetahuan yang dimiliki individu mengenai dirinya sendiri, pengharapan yang dimiliki individu mengenai dirinya sendiri, serta penilaian mengenai diri sendiri.

\section{Pengetahuan}

Aspek pertama dari konsep diri adalah pengetahuan. Pengetahuan yang dimiliki individu merupakan apa yang individu ketahui tentang dirinya sendiri. Hal ini mengacu pada istilah-istilah kuantitas seperti usia, jenis kelamin, kebangsaan, 
pekerjaan, lain-lain. Sedangkan hal-hal yang mengacu pada istilah-istilah kualitas seperti individu, egois, baik hati, tenang, dan bertempramen tinggi. Pengetahuan bisa diperoleh dengan membandingkan diri individu dengan kelompok pembandingnya. Pengetahuan yang dimiliki individu tidaklah menetap sepanjang hidupnya, pengetahuan bisa berubah dengan cara merubah tingkah laku individu tersebut atau dengan cara merubah kelompok pembanding (Calhoun dan Acocella, 1990).

Individu mendefinisikan dirinya berdasarkan apa yang mereka lakukan, apa yang mereka miliki, dan karakteristik pribadi yang membuat mereka berbeda dengan individu lain. Pengetahuan dibangun dengan melakukan suatu praktek tindakan, bukan hanya menggunakan emosi dan keinginan saja. Jadi pengetahuan diri ditentutakan oleh hubungan antara diri ideal dan citra diri atau cara melakukan kegiatan sehari-hari dibandingkan dengan cara tersendiri bila telah berhasil menjadi diri ideal. Pengetahuan diri yang tinggi adalah dasar dari sebuah konsep diri yang positif dan merupakan unsure penting untuk mencapai keberhasilan (Rahmawati, 2005).

Pengetahuan diri juga dapat dilihat dengan label-label dan simbol-simbol yang diberikan pada diri sendiri oleh individu-individu yang bersangkutan untuk menggambarkan dirinya dan membangun identitasnya, kemudian dengan bertambahnya usia dan interaksi dengan lingkungannya, pengetahuan individu tentang dirinya juga bertambah, sehingga ia dapat melengkapi keterangan tentang dirinya dengan hal-hal yang lebih kompleks (Aikesari, 2008).

Sementara Pudjijogyanti (1995) menjelaskan bahwa pengetahuan diri adalah seluruh sikap dan pandangan individu terhadap dirinya yang akan sangat mempengaruhi individu dalam menafsirkan pengalamnnya. Setiap pengalaman diberi arti tertentu oleh individu, dimana pemberian arti tersebut dipengaruhi oleh bagaimana ia memandang dirinya. Jika individu memiliki pandangan yang positif dan menyenangkan, maka ia akan menafsirkan pengalamannya secara positif. Begitu pula sebaliknya, dimana tafsiran negatif berasal dari konsep diri yang negatif pula.

Pengetahuan diri juga merupakan perasaan atau persepsi seseorang tentang keadaan pribadinya. Hal ini tidak dipengaruhi oleh kondisi fisik atau hubungan dengan orang lain, tetapi dipengaruhi oleh sejauh mana individu merasa puas terhadap pribadinya atau sejauh mana ia merasa dirinya sebagai pribadi yang tepat. Apa yang dipikirkan dan di rasakan oleh seseorang akan menentukan apa yang dikerjakannya (Centi, 1993).

\section{Harapan}

Aspek kedua dari konsep diri adalah harapan. Selain individu mempunyai satu set pandangan tentang siapa dirinya, individu juga memiliki satu set pandangan lain, yaitu tentang kemungkinan menjadi apa di masa mendatang. Singkatnya setiap individu mempunyai pengharapan bagi dirinya sendiri dan pengharapan tersebut berbeda-beda pada setiap individu (Calhoun dan Acocella, 1990).

Centi (1993) yang dikutip oleh Aikesari (2008) juga menjelaskan bahwa dengan pengharapan yang dimiliki, individu dapat melakukan estimasi tentang apa respon orang lain terhadap dirinya. Dengan demikian konsep diri menentukan 
harapan individu tentang apa yang terjadi. Seseorang yang mempunyai penilaian dirinya mampu menyelesaikan tugas dengan baik akan mengharapkan orang lain tersebut untuk menghargainya seperti ia menghargai dirinya.

Seorang individu juga cenderung akan berperilaku sesuai dengan pengharapan orang yang ada disekitarnya. Bila pengaharapan ini konsisten dengan waktu dan individu-individu tersebut, maka seseorang akan cenderung memperlihatkan tingkah laku yang konsisten dengan pengaharapan tersebut (Maulana, 2011).

\section{Penilaian}

Aspek terakhir dari konsep diri adalah penilaian terhadap diri sendiri. Individu berkedudukan sebagai penilai terhadap dirinya sendiri setiap hari. Penilaian terhadap diri sendiri adalah pengukuran individu tentang keadaannya saat ini dengan apa yang menurutnya dapat dan terjadi pada dirinya (Calhoun dan Acocella, 1990). Ditambahkan pula menurut Centi (1993) yang dikutip oleh Rulia (2008) bahwa penilaian yang dilakukan individu adalah bagaimana individu merasa tentang dirinya sebagai pribadi yang dipikirkannya.

Konsep diri sebagai suatu penilaian terhadap penampilan, perilaku, perasaan, sikap-sikap, kemampuan, serta sumber daya yang dimiliki seseorang. Konsep diri sebagai suatu penilaian terhadap diri juga dijelaskan dalam definisi konsep diri yang di kemukakan oleh Patosuwido (2002) yaitu bahwa konsep diri adalah cara bagaimana individu menilai diri sendiri, bagaimana penerimaannya terhadap diri sendiri, bagaimana yang dirasakan, diyakini, dan di lakukan, baik ditinjau dari segi fisik, moral, keluarga, personal, dan sosial. Penilaian diri juga penilaian antara pengharapan mengenai diri seseorang dengan standar dirinya yang akan menghasilkan penilaian diri yang dapat berarti seberapa besar seseorang menyukai dirinya sendiri.

Burns (1993) juga menjelaskan dengan adanya penilaian terhadap dirinya sendiri, individu akan menentukan apakah ia dapat menerima dirinya sendiri atau melakukan penolakan atas dirinya. Seseorang akan memiliki penilaian diri yang tinggi bila ia menerima dirinya sendiri, dan sebaliknya jika ia tidak menerima dirinya sendiri, maka ia akan memiliki konsep diri yang negatif. Konsep diri juga berfungsi sebagai pengamat, penentu standar, pembanding, dan yang terutama adalah sebagai penilai diri atau evaluasi.

Konsep diri terkait dengan bagaimana sebenarnya individu menilai dirinya melalui sikap dan perilaku yang telah di cerminkan dalam kehidupan sehari-harinya secara pribadi. Manusia cenderung memberikan penilaian terhadap apa yang di persepsikannya. Oleh karena itu label-label yang di kenakan pada dirinya bukanlah semata-mata menggambarkan dirinya, tetapi juga sarat dengan nilai- nilai. Selanjutnya penilaian ini lebih berperan dalam menentukan tindakan yang akan di tampilkannya (Rulia, 2008).

Partosuwido (1992) juga menjelaskan bahwa penilaian didefinisikan sebagai kecenderungan untuk memandang diri sendiri sebagai pribadi yang mampu dan memiliki daya upaya dalam menghadapi tantangan-tantangan hidup yang mendasar dan layak untuk hidup bahagia. Atau lebih mudahnya penilaian diri di definisikan 
sebagai seberapa suka kita terhadap diri kita, dan menghormati diri kita sendiri sebagai seseorang yang berharga dan bermakna, maka akan semakin tinggi penilaian terhadap diri sendiri. Semakin kita merasa sebagai manusia yang berharga, maka kita semakin positif dan bahagia.

Diri penilai menentukan kepuasan seseorang akan dirinya atau seberapa jauh seseorang menerima dirinya. Kepuasan diri yang rendah akan menimbulkan penilaian diri yang rendah pula, dan akan mengembangkan ketidakpercayaan yang mendasar pada dirinya. Sebaliknya, bagi individu yang memiliki kepuasan diri yang tinggi, kesadaran dirinya lebih realistis sehingga lebih memungkinkan individu yang bersangkutan untuk melupakan keadaan dirinya dan memfokuskan energi serta perhatiannya untuk dapat berfungsi lebih konstruktif (Pudjijoyanti, 1995).

Penilaian individu terhadap bagian-bagian dirinya dalam dimensi eksternal dapat dipengaruhi oleh penilaian dan interaksinya dengan orang lain. Seseorang tidak dapat begitu saja menilai bahwa ia memiliki fisik yang baik tanpa adanya reaksi dari orang lain yang memperlihatkan bahwa secara fisik ia memang menarik. Demikian pula seseorang tidak dapat mengatakan bahwa ia memiliki diri pribadi yang baik tanpa adanya tanggapan atau reaksi orang lain di sekitarnya yang menunjukan bahwa ia memang memiliki pribadi yang baik (Centi, 1993).

\section{Kritik Sosial}

Kritik adalah kecaman atau tanggapan, kadang-kadang disertai uraian dan pertimbangan baik atau buruk terhadap sesuatu hal. Sedangkan sosial adalah hal yang berkenaan dengan masyarakat. Menurut Astrit Susanto "Kritik sosial adalah penilaian ilmiah ataupun pengujian terhadap situasi masyarakat pada suatu saat" (Amin Rais, 1986). Masyarakat dalam situasi dan kondisi tertentu dapat dikaji melalui penilaian dan pengujian yang bersifat ilmiah, dapat menghasilkan suatu pandangan tertentu bagi orang yang mengkajinya. Biasanya pengkajian ini dalam situasi dan kondisi yang dirasa memprihatinkan bagi beberapa orang ataupun bagian dari masyarakat.

Kritik sosial dinilai sebagai barometer sosial politik suatu masyarakat. Adanya pendapat-pendapat yang menginginkan koreksi, perbaikan dalam masyarakat menjelaskan adanya perubahan (Amin Rais, 1986). Kritik sosial hadir atas dasar keinginan untuk suatu perubahan sosial politik yang menyangkut normanorma dan aturan yang berkembang di kalangan masyarakat. Dengan adanya kritik sosial, diharapkan akan terjadinya suatu keadaan yang lebih baik dari sebelumnya.

Kritik sosial ditandai dengan adanya kejadian dan fenomena sosial yang dianggap tidak masuk akal dan tidak rasional, sehingga menimbulkan pemikiran yang kritis dan logis untuk melihat kejadian dan fenomena tersebut. Hal ini didasari oleh suatu keyakinan yang berdasarkan dari pengetahuan dan pengalaman yang didapat. Kehadiran kritik sosial tentunya merupakan gejolak masyarakat atas suatu keadaan yang tidak memuaskan, sehingga adanya sebuah dorongan untuk melakukan hal yang dapat menetralisirnya.

Absolutisme kekuasaan pemimpin menyebabkan bahwa ketakutan meresapi semua lapisan masyarakat dan menjadi faktor yang paling menentukan dalam mengendalikan situasi (K. J. Veeger,1985). Tatanan politik semacam ini, biasanya 
muncul pada masyarakat di bawah pemerintahan yang otoriter. Keadaan yang otoriter, tidak memberi toleransi pada masyarakat yang menuntut layanan di luar yang telah mereka programkan dan harus menerima secara apa adanya, tanpa boleh dimodifikasi atau diubah.

Berangkat dari hal tersebut, salah satu contoh kehadiran kritik sosial bisa ditemukan, dan keadaan seperti ini cenderung menuntut suatu perubahan sosial yang diinginkan. Oleh karena itu, dasar kritik sosial terletak dalam tujuan yang mengharapkan suatu keadaan dapat berubah. Suatu rasional universal yang di dalamnya setiap orang berpartisipasi, untuk mendapatkan suatu kondisi yang lebih baik dari kesepakatan nilai-nilai yang diharapkan.

Namun dalam melakukan sebuah kritik sosial, perlu adanya suatu motivasi untuk membangun, bukan untuk menjatuhkan. Karena seperti yang dikutip Hafied Cangara, "Kritik sosial adalah salah satu bentuk komunikasi dalam masyarakat yang bertujuan atau berfungsi sebagai kontrol terhadap jalannya sebuah sistem sosial atau proses bermasyarakat". (Cangara, 2009). Oleh karena itu kehadiran kritik sosial, bukan untuk menambah perkeruh suasana dan menciptakan konflik baru, namun digunakan sebagai kontrol sosial untuk menciptakan nilai-nilai yang diharapkan dengan kesepakatan bersama.

\section{Mural}

Mural berasal dari bahasa Latin, yaitu dari kata murus yang berarti dinding. Dalam pengertian kontemporer, mural adalah lukisan berukuran besar yang dibuat pada dinding, langit-langit, atau bidang datar lainnya. Berbeda dengan graffiti yang hanya menekankan pada isi tulisan dan kebanyakan dibuat pada cat semprot, maka mural tidak demikian. Mural lebih bebas dan dapat menggunakan media cat tembok atau cat kayu. Bahkan cat atau pewarna apapun juga, seperti kapur tulis atau alat yang dapat menghasilkan gambar (Adi Kusrianto, 2010).

Mural atau sering diistilahkan lukisan dinding merupakan hasil kreasi dari orang-orang yang mempunyai bakat lukis. Mural merupakan seni grafis yang awalnya digunakan sebagai ekspresi artistik. Perkembangan fungsi mural mengandung pesan kritik sosial sebagai reaksi perlawanan dan pergolakan yang muncul di tengah-tengah masyarakat ataupun terhadap kebijakan pemerintah yang tidak sejalan dengan kepentingan rakyat.

Ada sisi lain yang perlu diketahui dari mural itu sendiri. Mural yang ada pada saat ini tidak hanya menekankan nilai-nilai estetik saja, tetapi ada yang lebih esensial dari pada hal tersebut, yaitu sebagai penyampai ide, gagasan, kritik, dan saran. Mural sebagai salah satu unsurnya adalah sebuah teks dan sistem tanda yang berorganisir menurut kode-kode yang merefleksikan nilai-nilai tertentu, sikap, dan keyakinan tertentu. Setiap pesan dalam mural memiliki dua tingkatan makna, yaitu makna yang dikemukakan secara eksplisit di permukaan dan makna yang dikemukakan secara implisit di balik permukaan tampilan gambar (Yuana Agus Dirgantara, 2012).

Karya mural dimulai jauh sebelum peradaban modern, bahkan diduga sejak 30.000 tahun sebelum Masehi. Sejumlah gambar prasejarah pada dinding gua di Altamira di Spanyol dan Lascaux di Perancis, yang melukiskan aksi-aksi berburu, 
meramu, dan aktifitas religius, kerapkali disebut sebagai bentuk mural generasi pertama. Pencitraan serupa ternyata ditemukan pula di Indonesia. Sejumlah gua kapur di Maros dan dinding-dinding kapur di Kolonodale, Sulawesi Tengah juga menyimpan gambar dinding dari masa prasejarah. Termasuk dalam mural generasi pertama antara lain imaji-imaji pada dinding piramid di Mesir, bangunan-bangunan pada masa Romawi, Yunani, Maya, juga tempat-tempat pemujaan di India dan Tibet.

Mural-mural abad pertengahan atau periode Baroque memperlihatkan lompatan besar pada tema dan teknik. Interior gereja-gereja di Italia, misalnya, diperindah dengan rerupaan bergaya surealis, karya Michaelangelo dan Leonardo da Vinci, yang bersumber pada kisah-kisah Al Kitab. Pada masa itu, rumah orangorang kaya di Prancis, Inggris, dan Jerman dianggap trendy jika interiornya dilengkapi dengan mural. Teknik yang populer digunakan saat itu adalah Fresco, yakni melukis dinding dengan cara mencampurkan pewarna dengan pelapis dinding (semacam semen), sehingga mural bertahan lama.

Mural kontemporer, dengan tema politik, sosial, dan industrial, mulai populer terutama sejak Diego Rivera dan beberapa koleganya menggoreskan kuas pada dinding-dinding kota Mexico City. Mural ini dibuat atas permintaan pemerintah revolusioner Mexico, dimaksudkan untuk menggugah semangat revolusi rakyat. Di Amerika Serikat, pemerintahan FD Roosevelt merilis program Work Progress Administration (WPA), semacam program padat karya yang melibatkan seniman untuk membuat mural bertema kampanye kembali bekerja seusai masa resesi dunia pada pertengahan 1930-an. Berawal dari program WPA, kota seperti San Francisco berkembang menjadi rujukan mural dunia.

Di Indonesia, karya rupa dalam bentuk mural memang tidak sepopuler lukisan, patung, atau grafis dan jarang disinggung dalam diskursus seni rupa. Secara sporadis, dalam berbagai bentuknya, karya mural ditemukan di berbagai daerah bahkan sejak masa revolusi kemerdekaan. Namun baru-baru ini saja, mulai tahun 2000-an, mural banyak disebut-sebut media dan publik seni rupa, meskipun hanya terbatas di kota-kota yang sudah lama marak dengan kegiatan seni rupa seperti Yogyakarta, Bandung, dan Jakarta. Pada tahun itu, di ketiga kota tersebut kaki-kaki jembatan layang dan dinding-dinding ruang publik diserbu mural (yusuparpiyan.blogspot.com/2012/09/).

\section{Artis Street Art}

Artis sebagai profesi dalam dunia seni. Untuk profesi di dunia film, mural dan hiburan. Seniman adalah istilah subyektif yang merujuk kepada seseorang yang kreatif, atau inovatif, atau mahir dalam bidang seni. Penggunaan yang paling kerap adalah untuk menyebut orang-orang yang menciptakan karya seni, seperti lukisan, patung, seni peran, seni tari, sastra, film,mural dan musik. Seniman menggunakan imajinasi dan bakatnya untuk menciptakan karya dengan nilai estetik. Ahli sejarah seni dan kritikus seni mendefinisikan seniman sebagai seseorang yang menghasilkan seni dalam batas-batas yang diakui (Wikipedia, 2014).

Street Art atau Seni jalanan adalah setiap seni yang dikembangkan di ruang publik seperti, "di jalanan" - meskipun istilah unsanctioned biasanya mengacu pada 
seni, sebagai lawan dari inisiatif yang disponsori pemerintah. Istilah ini dapat mencakup tradisional karya seni grafiti, mural, stencil graffiti, sticker art, poster jalanan wheatpasting, video proyeksi, seni intervensi, gerilya seni, flash mobbing dan instalasi jalan. Biasanya, istilah seni jalanan atau yang lebih spesifik pada seni grafiti yang dapat digunakan untuk membedakan ruang publik kontemporer karya seni dari graffiti teritorial, vandalisme, dan seni perusahaan (http://bit.ly/copy_win).

\section{METODOLOGI}

Penelitian ini mengunakan paradigma interpretif yang bertujuan untuk membangun dan mengonstruksi sesuatu kehidupan sosial berdasarkan setting alamiah (Newman, 2003). Pendekatanya adalah kualitatif adalah penelitian yang menghasilkan data deskriptif berupa ucapan, tulisan dan perilaku orang-orang yang diamati. Peneliti menentukan kriteria dari orang-orang yang dijadikan koresponden, yaitu Artis Street Art dalam Menghasilkan Mural "Kritik Sosial” di Jakarta.

\section{Informan Penelitian}

Kemudian informan dipilih Peneliti merupakan perwakilan dari Artis Street Art dalam Menghasilkan Mural "Kritik Sosial" di Jakarta. Dengan kriteria sudah berpengalaman lebih dari 5 tahun, berdomisili di Jakarta khususnya, Artis Street Art dalam Menghasilkan Mural "Kritik Sosial". Adapun yang dijadikan informan Ryan Riyadi.

Teknik dalam penelitian kualitatif ini adalah purposive sample (teknik sampel bertujuan) dimana sample diambil dengan melalui pertimbangan tertentu sesuai dengan tujuan penelitian.

\section{HASIL PENELITIAN DAN PEMBAHASAN}

Pada bab ini peneliti mencoba menguraikan data yang didapat, kemudian hasil penelitian yang sebelumnya telah dirumuskan pada bab I. Rumusan masalah pada bab I ini, ialah Bagaimana Konsep Diri Artis Street Art dalam Menghasilkan Mural "Kritik Sosial" di Jakarta.

Dengan wawancara mendalam serta observasi peneliti mendapatkan data penelitian, yang kemudian dianalisis kemudian diuraikan dalam hasil penelitian dan pembahasannya di bab IV ini.

Penelitian ini juga menggunakan pendekatan kualitatif untuk melihat kondisi alami dari suatu permasalahan yang peneliti ambil. Pendekatan ini bertujuan memperoleh pemahaman dan menggambarkan realitas yang kompleks.

Peneliti dalam penelitiannya menganalisis artis street arts, dalam hal ini konsep diri seorang street arts. Sehingga dapat terlihat bagaimana konsep diri street arts ketika menghasilkan mural kritik sosial. Konsep Diri dijadikan indikator yang mempengaruhi karya artis street arts dalam menghasilkan karyanya, terutama mural kritik sosial.

Dengan harapan penelitian ini lebih baik dan akurat, maka peneliti mencoba menambahkan data dari hasil wawancara, observasi, atau dokumentasi sebagai penambah data utama yang didapat melalui wawancara mendalam serta observasi. Peneliti mencoba memaparkan segala yang didapatkan selama melakukan penelitian 
atau pun selama masa pra-penelitian. Dituangkan secara menyeluruh, dan deskriptif sebagai metodenya. Dimana peneliti berperan layaknya yang diteliti dalam melakukan aktifitas melukis, dalam hal ini sebagai artis street arts dengan konsep dirinya masing-masing ketika akan melukis mural kritik sosial

Agar pembahasan dalam penelitian ini lebih sistematis dan terarah maka Peneliti membagi ke dalam 2 (dua) pembahasan, yaitu:

\section{HASIL PENELITIAN}

\section{Popo, Pelukis Mural Pengkritik sosial}

Ryan Riyadi adalah salah-satu seniman jalanan, atau street artist, yang karya-karyanya banyak menghiasi berbagai tembok di ruang publik di Jakarta yang sebagian berisi kritik sosial.

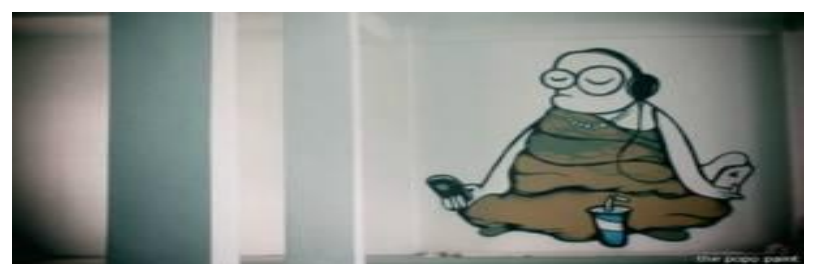

Gambar 1. Karya mural Ryan 'Popo' Riyadi di sebuah lokasi yang tertutup.

Selama sekitar dua belas tahun menjadikan tembok sebagai medium artistiknya, pria kelahiran 1980 ini lebih dikenal melalui karakter gambar hasil rekaannya yaitu The Popo. Berbeda dengan pelukis grafiti kebanyakan yang sekedar memanfaatkan tembok kosong, peraih penghargaan The Best Mural Artist pada Tembok Bomber Award 2010 ini mengaku memiliki konsep dan tujuan dalam setiap berkarya.

"Awal mula saya interest (tertarik) untuk menggambar di satu tempat, itu adalah cerita," kata Ryan Ryadi. "Saya hunting bukan tembok kosong dulu," kata Ryan, yang juga dosen komunikasi visual di almamaternya, Institut Ilmu Sosial dan Ilmu Politik di Jakarta.

Dia juga mengaku tidak terlalu memusingkan apakah karya muralnya itu bakal menyedot perhatian orang banyak atau tidak."Intinya, saya menceritakan history (sejarah) yang ada di sekitar tembok itu," katanya menjelaskan filosofinya dalam berkarya. "Jadi, tembok dan lingkungan itu ada korelasinya."

Dengan kata lain, lanjutnya,"nggak sekedar ngomongin mural, tapi ngomongin ruang itu sendiri".

Ryan lantas menceritakan pengalaman estetikanya saat melukis mural di kawasan Jalan Prapanca, Jakarta Selatan, sekian tahun silam.

Di sebuah siang, ketika mengendarai sepeda motor melewati jalan raya tersebut, anak bungsu dari tiga bersaudara ini menyaksikan beberapa pohon ditebang untuk kepentingan pembangunan jalan layang (fly over).

"Setiap hari lewat jalan itu, otomatis saya kepanasan dong, karena pohonpohon itu sudah nggak ada lagi," ungkapnya membuka cerita. 
Pengalaman langsung bersentuhan dengan realitas seperti inilah, menurut Ryan, banyak melatari karya-karya grafitinya dalam dua belas tahun terakhir.

"(Secara) Spontan, saya siapkan cat warna merah. Saya (lantas) menulis: 'Demi fly over, pohon game over' dan ada kepala karakter si Popo sebagai teks saya, sebagai tanda saya, sebagai seniman," jelas Ryan, yang pernah ikut dipercaya tampil dalam pameran mural dan instalasi di Singapura ini.

"Yang penting saya ngerasain dulu apa yang ada di ruang itu," katanya, menjelaskan lebih lanjut. Intinya, saya menceritakan history (sejarah) yang ada di sekitar tembok itu. Jadi, tembok dan lingkungan itu ada korelasinya... nggak sekedar ngomongin mural, tapi ngomongin ruang itu sendiri.

\section{Bukan Sosok Robin Hood}

Lukisan Mural Ryan yang menyoroti pembangunan jalan layang di atas Jalan Prapanca itu, kemudian menyedot perhatian masyarakat. Sejumlah media nasional kemudian memberitakannya.

Kebetulan, ketika itu, sebagian warga yang tinggal di kawasan tersebut serta pegiat lingkungan juga melayangkan protes. Pria yang sejak kecil tertarik dunia melukis ini masih ingat ketika karyanya itu "dibahas" panjang-lebar di situs sosial Twitter."Oh, ternyata banyak yang merasa diwakilkan (aspirasinya melalui gambar mural itu)," kata Ryan.

Namun demikian, sambungnya cepat-cepat, dia sama-sekali tidak berpretensi untuk menjadi pahlawan dalam polemik pembangunan jalan layang tersebut."Posisi saya nggak seperti Robin Hood, yang tiba-tiba saya (menjadi) heroik untuk membikin suatu karya," katanya dengan nada tegas.

Ryan juga menandaskan, bahwa dalam setiap berkarya, dia tidak pernah mengatasnamakan apa yang disebutnya sebagai "aspirasi rakyat"."Kalau ada yang merasakan terwakilkan, ya, itu efek," katanya pendek. Posisi saya nggak seperti Robin Hood, yang tiba-tiba saya (menjadi) heroik untuk membikin suatu karya.

\section{Pengetahuan}

Dari semua karya Mural Ryan di berbagai tembok di jalanan Ibu kota, sebagian besar diantaranya memuat kritik sosial. "Karena paling dekat," kata Ryan, saat saya menanyakan apa motivasinya memuat kritik sosial dalam karya-karya muralnya."Saya nggak akan ngomong kehidupan yang jauh-jauh".

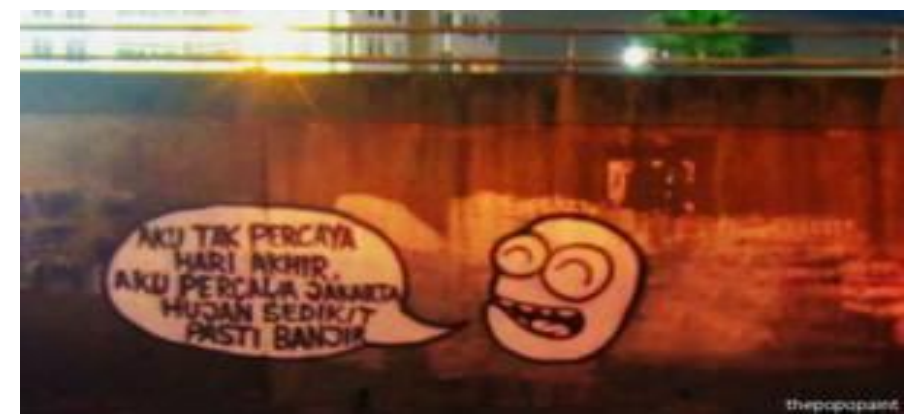

Gambar 2. Karya mural Ryan Riyadi kental dengan kritikan sosial. 
Menurutnya, kehidupan sosial merupakan realitas yang paling dekat dengan dirinya. "Minimal baru saja saya lewatin," tambahnya. Dengan berpijak pada realitas sosial di sekelilingnya, membuatnya "tidak perlu meraba-raba" dalam melahirkan karya seninya.

Lalu, apakah Anda bertujuan mengubah keadaan melalui mural yang berisi kritik sosial itu? Tanya saya lagi."Itu kayak semacam diary visual," jawabnya. "Sama saja sih seperti kita di tengah macet, terus kita nge-tweet".

Dia lantas mencontohkan karya muralnya 'Jangan pucet lihat Jakarta macet' di tembok tol TB Simatupang, Jakarta Selatan, yang menyoroti persoalan kemacetan di Jakarta. "Terus ada orang yang bertanya: 'tujuannya apa (membuat mural soal macet), biar (Jakarta) nggak macet? Nggak!"

Dengan kata lain, menurutnya, pembuatan mural yang bermuatan kritik sosial tidak bertujuan untuk mengubah keadaan. "Mengeluarkan, intinya," katanya, singkat. "Motivasinya ya cuma ingin mengeluh, atau ingin menyampaikan sesuatu. Sama seperti buku diary."Itu kayak semacam diary visual. Sama saja sih seperti kita di tengah macet, terus kita nge-tweet.

\section{Harapan}

Popo merupakan karakter gambar yang selalu menyertai karya-karya mural Ryan Riyadi. "Kalau seniman lain ada tanda tangan (di dalam karyanya), kalau saya si karakter Popo. Jadi saya 'nggak perlu tanda tangan," kata Ryan, menggambarkan 'kedekatannya' dengan karakter Popo.

Bentuk fisik Popo merupakan manifestasi tubuh manusia, dengan mata melotot, tanpa hidung dan (sering tanpa) rambut, kepala lonjong, serta cenderung tanpa jari-jemari.

Secara sekilas karakter Popo mirip dengan karakter tokoh kartun Patrick dalam film seri kartun Spoonge Bob di layar kaca.

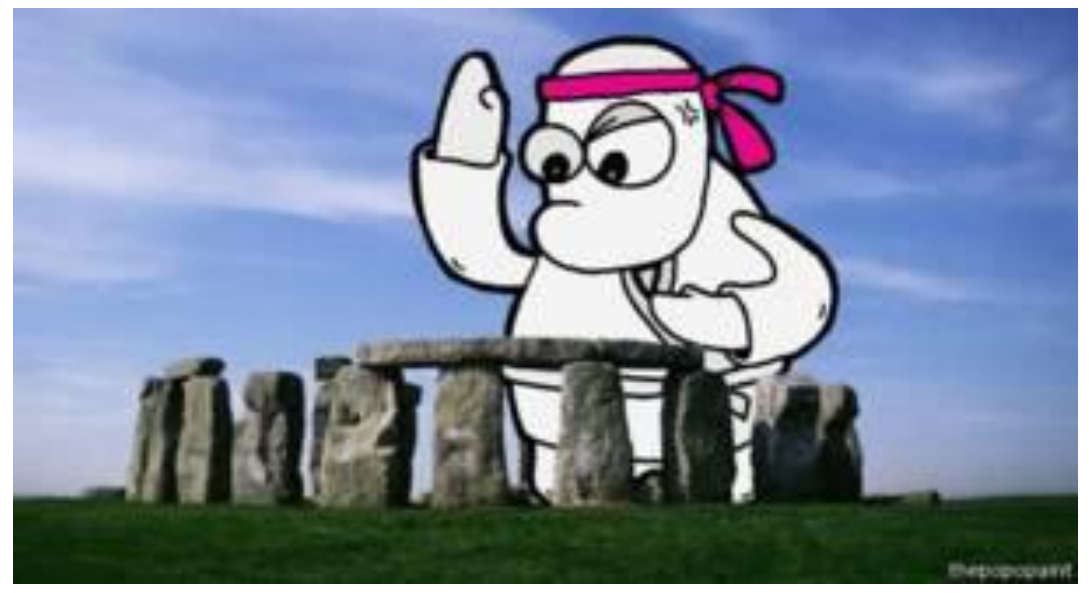

Gambar 3. Karakter Popo, dengan mata melotot, merupakan akronim positif progresif. 
"Itu kebetulan saja," kata Ryan, ketika saya menanyakan kemiripan sosok Popo dengan tokoh kartun tersebut.

"Memang karakter mata belok(melotot), terus bentuknya lonjong-lonjong, itu gampang dihafal," jelasnya, lebih lanjut.

"Anak kecil untuk menggambar (karakter) Spoonge Bob dan Patrick, itu lebih gampang untuk menggambar Patrick".

"Karena," imbuhnya, "untuk me-maintenance garis-garis visual itu lebih gampang Patrick. Tinggal bulat-bulat lonjong".

Pada akhirnya, sosok karakter ciptaannya, yaitu Popo, lebih banyak dikenal masyarakat ketimbang sosok pribadi Ryan sendiri.

Itulah sebabnya, orang-orang yang mengenal karyanya lebih sering memanggilnya dengan sebutan "Popo".

Tetapi, betulkah nama Popo itu singkatan dari 'positif progresif'?

Ryan membenarkan. "Itu kayak doa kecil. Satu langkah kebaikan. Semoga karya gua satu langkah lebih baik dari sebelumnya."

Beberapa kali BBC Indonesia meminta agar Ryan mengirimkan foto dirinya untuk kebutuhan ilustrasi tulisan ini, tetapi secara halus dia tidak pernah menuruti permintaan ini.

"Sebenarnya bukan saya mau anonim ya," terang Ryan, tentang keenganannya menyertakan foto dirinya untuk kebutuhan pemberitaan.

Namun demikian, dia akhirnya mengaku, kebiasaan ini tidak terlepas dari strateginya untuk mengenalkan karakter Popo ke masyarakat.

"Saya ingin ngenalin Popo ini," aku pengagum pelukis mural terkenal asal Inggris, Banksy, yang dikenal misterius dan jarang menampilkan sosoknya di depan umum ini

Itulah sebabnya, masih menurut pengakuannya, dia sering menolak permintaan wartawan untuk memotret dirinya.

Hal ini rupanya berlaku pula buat BBC Indonesia, walaupun Ryan mempersilakan memuat foto dirinya jika saya menemukan potretnya di situs sosial miliknya.

Apa keinginannya yang selama ini belum terlaksana. Dengan nada bersemangat, Ryan berkata: "Saya ingin (membuat) bantal dan saya bagikan kepada orang-orang".

"Orang mampu boleh memiliki, orang susah juga boleh memiliki. Tapi saya utamakan orang yang tidur di jalan". Di atas bantal itu, Ryan bercita-cita menuliskan sebuah kalimat "masa depan berawal dari mimpi".

Melalui pesan itu, dia ingin mengatakan kepada semua orang: "Kamu tidur saja, kamu mimpi saja. Setelah semua selesai, kamu akan beraktivitas, dan mewujudkan semuanya".

"Penginnya itu aja sih. Mau nge-bagiin bantal dan mau ngingetin kita harus tetap semangat," katanya. "Saya pengin bikin saya teman-teman di jalan, yang tidur di jalan, di trotoar, di halte, agar mereka tetap merasakan empuknya bantal dan sekalian dibikin semangat," tambah Ryan, sekaligus menutup wawancara sore itu. 


\section{Penilaian}

Walaupun demikian, Ryan termasuk rajin memotret karya-karya muralnya, setelah dia menyelesaikannya. Hal ini dia lakukan secara sadar karena karya seninya bakal dihapus oleh Satuan Polisi Pamong Praja, karena dianggap mengotori sarana dan prasarana umum.

"(Saya) Selalu (memotretnya). Jadi saya sadar ini nggak akan lama. Jadi saya foto langsung," akunya, agak tergelak.Menurutnya, aksi menggambar mural lalu disusul aksi menghapus mural tersebut merupakan sesuatu yang lumrah bagi dirinya.

"Ya, akhirnya kuat-kuatan saja. Saya yang gambar atau mereka yang menghapus. Lebih kuat mana," imbuhnya, kali ini dengan tertawa. Itulah sebabnya, saat ini sangat sulit menjumpai karya Ryan di tembok-tembok di ruang publik di wilayah Jakarta dan sekitarnya.

"Hampir semua (sudah dihapus), kecuali yang di hidden spot (tempat tersembunyi). Hidden spot itu biasanya di rumah-rumah kosong, gudang, di daerah pedesaan, atau di luar kota yang memang jauh".

Tentu saja, tidak setiap saat Ryan taat untuk memotret hasil karya muralnya. "Saya sempat beberapa kali kecolongan 'nggak foto karya saya, tapi saya cari di internet, banyak orang yang mengabadikannya. Kayak citizen journalism. Jadi mereka foto karya saya. Jadi mereka mewakili mendokumentasikan karya saya. Saya tinggal save as (menyimpan) saja," katanya agak terkekeh.

Jika diperhatikan secara teliti, karya-karya mural Ryan Riyadi sangat kental dengan unsur jenaka, selain bernada satir dan kritikan.

Menurutnya, unsur jenaka mewarnai sebagian karyanya tidak terlepas dari pengaruh mendiang ayahnya. "Karena gen keluarga dan almarhum ayah saya, memang selalu bercanda untuk membicarakan apapun," ungkapnya, dengan nada bergetar. Ayahanda Ryan Riyadi meninggal dunia pada awal Mei 2013 lalu akibat sakit."Almarhum pernah mengatakan: masalah seberat apapun, kalau disampaikan secara humor, secara ringan, itu akan masuk, itu akan diterima," katanya, menjelaskan.

"Jadi ini sudah gen ayah saya yang masuk ke saya. Sudah ada mengalir ke saya," katanya lagi. "Untuk menceritakan segala sesuatu seberat apapun, mesti dengan humor. Humor harus tetap ada". Namun demikian, akunya, "kalau saya suka menuliskan sesuatu yang satir".Semenjak awal Ryan mempunyai keinginan dan selalu termotivasi untuk meneruskan kuliah seni rupa, namun tidak terlaksana karena masalah biaya. Belakangan, pria yang tinggal di Bekasi, Jawa Barat ini, akhirnya melakukan eksplorasi di dunia seni rupa secara mandiri.

Hal ini juga yang melatari pilihannya untuk menekuni seni mural.Di lingkungan tempat tinggalnya di Bekasi, dia pertama kali tertarik seni grafiti ketika masih di bangku sekolah menengah.

Saat itu, dia sering menyaksikan sejumlah mahasiswa -- yang menjadi tetangganya -- menggambar mural pada tembok-tembok rumahnya."Saya kemudian tertarik," katanya, mengenang. Aktivitas seni mural yang semula terbatas di tembok rumah sendiri, di dalam kampung, akhirnya berkembang di tembok-tembok di luar tempat tinggalnya. 
Selain menggambar di ruang publik, Popo juga menumpahkan hasrat seninya ke berbagai media seperti kayu, kanvas, maupun media media unik lainnya, seperti instalasi atau digital printing.

Dia juga beberapa kali berkolaborasi dengan berbagai seniman mancanegara lainnya, termasuk ketika menggelar pameran bersama di Singapura, sebanyak dua kali beberapa tahun silam.

Di Singapura, salah-satu karya mural yang dikerjakannya bersama seniman dari komunitas Ruang Rupa (Ruru) adalah mural yang "ngomogin tentang Singapura" setinggi 60 meter kali 7 meter.

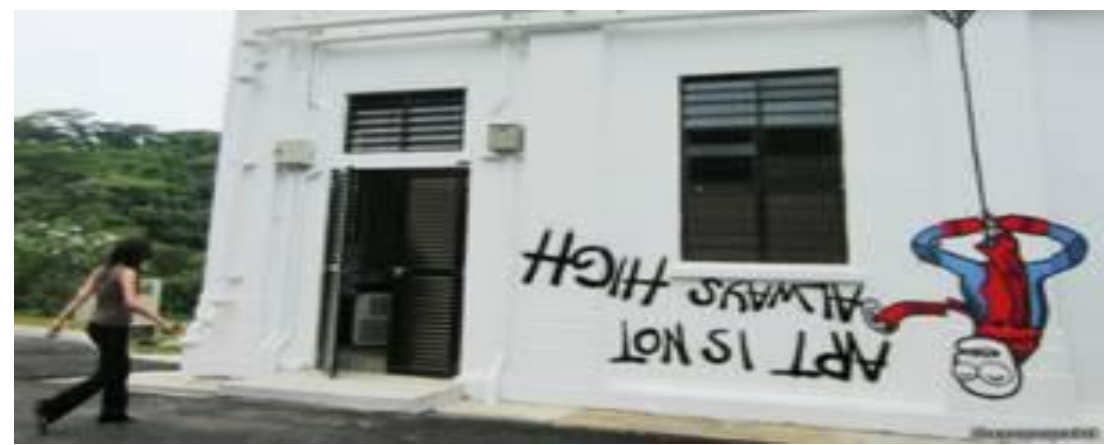

Gambar 4. Karya mural Ryan Riyadi ikut mewarnai sebuah pameran mural di Singapura.

"Selama 10 hari tinggal di sana, saya mempelajari kehidupan (masyarakat Singapura) dan saya bikin mural di sana. Misalnya, saya nulis, 'one nation under CCTV'. Karena di Singapura, banyak banget CCTV-nya," ungkapnya.

Di Singapura, tetapi dalam pameran yang berbeda, Ryan Riyadi juga diundang untuk menghasilkan karya seni mural, yang sampai sekarang tidak dihapus oleh pemilik galerinya."Karena pemilik galeri dan pemilik heritage suka," katanya.

Mural itu menggambarkan sosok Popo dengan tulisan 'Twitter I'm following You'. Di pameran itu, Ryan juga membuat mural dengan tulisan 'seni tidak selalu tinggi' dengan gambar sosok Spiderman dalam posisi terbalik.(www.bbc.com).

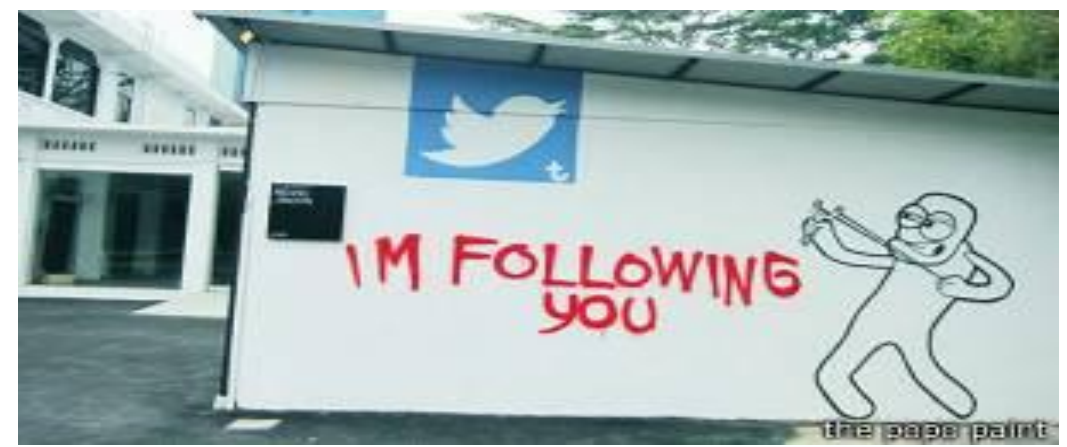

Gambar 5. Karya mural Ryan lainnya yang dipamerkan di Singapura. 


\section{PEMBAHASAN HASIL PENELITIAN}

Dari deskripsi penelitian di atas maka peneliti membahas konsep diri seorang artis street art dalam menghasilkan karya mural kritik sosial di kota Jakarta terlahir dari pengetahuan, pengharapan serta penilaian artis street art itu sendiri.

Pengetahuan artis street art tentang dirinya sendiri sangatlah penting, pengetahuan terbentuk dan berkembang dengan bagaimana kehidupan ia di keluarga, lingkungan. Pengetahuan akan dirinya ini akan membawa pemahaman apa yang ia kerjakan dan segala hal yang akan ia lakukan. Sebagai seorang artis street art dalam menghasilkan karyanya, pengetahuan secara umum bidang mural haruslah ia miliki. Akan tetapi dalam menghasilkan karya mural kritik sosial, pengetahuan dan pengalaman secara teknis mural tidaklah cukup.

Pengetahuan adalah informasi atau maklumat yang diketahui atau disadari oleh seseorang. Dalam pengertian lain, pengetahuan adalah pelbagai gejala yang ditemui dan diperoleh manusia melalui pengamatan akal. Pengetahuan muncul ketika seseorang menggunakan akal budinya untuk mengenali benda atau kejadian tertentu yang belum pernah dilihat atau dirasakan sebelumnya. Misalnya ketika seseorang mencicipi masakan yang baru dikenalnya, ia akan mendapatkan pengetahuan tentang bentuk, rasa, dan aroma masakan tersebut. (id.wikipedia.org/wiki/Pengetahuan).

Artis street art memiliki pengetahuan basic kemudian pengetahuan lain atau pendalamannya, walaupun pada akhirnya basic mural bagi.

Ideal diri adalah persepsi individu tentang bagaimana ia harus berperilaku sesuai dengan standar pribadi (Stuart \& Sundeen, 1991). Artis street art memiliki standar berprilaku yang menjadikan mereka memiliki prilaku dan pengetahuannya masing-masing.

Pengetahuan, artis street art harus mengerti dan memahami apa itu kritik sosial yang merupakan salah satu aliran dalam dunia Mural. Kritik sosial "Motivasinya ya cuma ingin mengeluh, atau ingin menyampaikan sesuatu".

Harapan yang timbul ketika artis street art tersebut membuat mural merupakan refleksi diri mereka terhadap lingkungan dan perkembangan dunia murali yang mereka jalani. Mural tanah airpun sangat kreatif dan tak kalah dengan mural luar negeri.

Individu juga memiliki satu set pandangan lain, yaitu tentang kemungkinan menjadi apa di masa mendatang (Rogers, dalam Calhoun \& Acocella, 1990).

Harapan masa akan datang, mereka bisa terus menghasilkan karya terbaik dengan eksplorasi tanpa batas untuk pecinta mural, kemudian mendapatkan apresiasi atau penghargaan tentang apa yang ia lakukan.

Penilaian menjadi pegangan mural dalam menghasilkan karyanya. Terutama kritik sosial. Dalam proses aktifitas melukis mural, konsep atau ide itu sendiri menjadi nilai paling utama. Agar karya mural tetap kepada arah dan sesuai ekspektasi Artis street art bisa lebih memperhatikan dan mempelajari karya mural mereka di Indonesia. Menjaga orisinilitas, dan mengindahkan tidak melakukan plagiat atau latah terhadap suatu tren, memberikan kontribusi penting untuk memajukan mural di tanah air. 
Konsep diri Artis street art bisa lebih memperhatikan dan mempelajari karya mural mereka di Indonesia tanpa harus melihat hasil karya fotografer luar sebagai bahan pembelajaran, Ryan Riyadi menjelaskan dengan adanya sentuhan pengalaman berdasarkan pengetahuan pengharapan, dan penilaian mereka. Mural tersebut akan memiliki nilai dengan adanya konsep diri Artis street art.

Sesuai dengan pengetahuan, harapan dan penilaian yang menjadi sub fokus penelitian ini, Peneliti mencoba mendeskripsikan konsep diri yang dimiliki informan mengacu kepada hasil wawancara serta observasi yang telah dilakukan. Ryan Riyadi memiliki konsep diri dalam menghasilkan mural kritik sosial dengan gambaran sebagai berikut: jujur dalam berkarya, kemudian memiliki mental yang kuat apabila karyanya dikritik orang, memiliki motivasi belajar yang tinggi, keinginan tinggi eksplorasi tanpa batas dalam berkarya, terbuka dalam menerima masukan . Ryan Riyadi selalu menjaga komunikasi dengan orang yang mempunyai ruang/tembok untuk menghasilkan karya mural kritik sosialnya.

Dengan konsep diri tersebut, Artis street art bagaimana usaha mereka dalam memperbaiki diri sehingga menuju arah kepada diri yang lebih baik dengan karya yang diterima oleh publiknya.

Konsep diri mengarahkan kepada kemampuan dan kematangan dalam berperilaku. Perilaku matang Artis street art dalam aktifitas mural dimulai sejak pembentukan konsep atau ide, hingga sentuhan akhir berupa karya mrual sesuai dengan harapan dan tujuan pelukisannya. Konsep diri Artis street art memperlihatkan secara jelas aktifitasnya, sehingga hal tersebut dibutuhkan dalam menghasilkan karya mural apapun termasuk mural kritik sosial.

\section{SIMPULAN}

Berdasarkan uraian-uraian yang telah dikemukakan pada bab-bab sebelumnya, serta analisis data maka simpulan data dari penelitian saya yang berjudul "Konsep Diri Artis Street Art dalam Menghasilkan Mural "Kritik Sosial" di Jakarta.

1. Pengetahuan, artis street art harus mengerti dan memahami apa itu kritik sosial yang merupakan salah satu aliran dalam dunia Mural.

2. Harapan yang timbul ketika artis street art tersebut membuat mural merupakan refleksi diri mereka terhadap lingkungan dan perkembangan dunia murali yang mereka jalani. Mural tanah airpun sangat kreatif dan tak kalah dengan mural luar negeri.

3. Penilaian menjadi pegangan mural dalam menghasilkan karyanya. Terutama kritik sosial. Dalam proses aktifitas melukis mural, konsep atau ide itu sendiri menjadi nilai paling utama. Agar karya mural tetap kepada arah dan sesuai ekspektasi Artis street art bisa lebih memperhatikan dan mempelajari karya mural mereka di Indonesia.

4. Artis street art memiliki konsep diri dalam menghasilkan mural kritik sosial dengan gambaran sebagai berikut: jujur dalam berkarya, kemudian memiliki mental yang kuat apabila karyanya dikritik orang, memiliki motivasi belajar yang tinggi, keinginan tinggi eksplorasi tanpa batas dalam berkarya, terbuka dalam menerima masukan. 


\section{DAFTAR PUSTAKA}

Agus, Dirgantara Yuana. (2012). Pelangi Bahasa Sastra dan Budaya Indonesia. Graudhawacana.

Aikesari. (2008). Konsep Diri Perkembangan dan Pengaruhnya Terhadap Pencapaian Akademik Siswa. Bandung.

Burns, R.B. (1993). Konsep Diri: Teori, Pengukuran, Perkembangan dan Prilaku. Jakarta: Arcan.

Cangara, Hafied. (2009). Komunikasi Politik, Konsep, teori, dan Strategi. Jakarta: Rajawali Pers.

Calhoun, F. \& Acocella, Joan Ross. (1990). Psikologi Tentang Penyesuaian dan Hubungan Kemanusiaan (Edisi Ketiga) Penerjemah: Satmoko, Semarang: IKIP Semarang Press.

Centi, J Paul. (1993). Mengapa Rendah Diri?. Yogyakarta: Kansius

Hurlock, E. B. (1990). Psikologi Perkembangan: Suatu Pendekatan Sepanjang Rentang Kehidupan. Alih Bahasa: Soedjarwo dan Iswidayanti. Jakarta: Erlangga.

http://dechantq.wordpress.com/street-art/ diakses pada 4 Maret 2014 (http://bit.ly/copy_win).

https://www.bbc.com/indonesia/majalah/2013/06/130618_tokoh_ryanriyadi_popo_p elukismural. diakses pada 8 Agustus 2014.

http://yusuparpiyan.blogspot.com/2012/09/pengertian-mural.html diakses pada 2 Mei 2013.

Kusrianto, Adi. (2010). Pengantar Tipografi. Jakarta: PT. Elex Media Komputindo.

Maulana, Gisaf. (2011). Konsep Diri Seorang Fotografer Dalam Menghasilkan Foto Glamour di Kota Bandung. Bandung: Universitas Komputer Indonesia.

Partosuwido, SR. (1992). Penyesuaian Diri Mahasiswa dalam Kaitannya dengan Konsep Diri, Pusat Kendali dan Status Perguruan Tinggi. Disertasi. Fakultas Pasca Sarjana Universitas Gajah Mada, Yogyakarta.

Pudjijogyanti, C.R. (1995). Konsep Diri dalam Pendidikan. Jakarta: Arcan 
Rais, Amin. (1986). Demokrasi dan Proses Politik. Jakarta: LP3ES, Cetakan Pertama.

Tinarbuko, Sumbo. (2009). Semiotika Komunikasi Visual. Yogyakarta: Jalasutra

Rahmawati, A. (2005). Hubungan Antara Konsep Diri dan Persepsi Tentang Peran Ganda Ibu Bekerja Dengan Ketakutan Akan Sukses Remaja Perempuan di Sekolah Kondukasi dan Non Kondukasi. Yogyakarta: Fakultas Psikologi Universitas Gajah Mada.

Rola, Fasti. (2006). Hubungan Konsep Diri Dengan Motivasi Berprestasi Pada Remaja. Medan: Universitas Sumatera Utara.

Rulia, Mirna. (2008). Konsep Diri Perkembangan dan Pengaruhnya Terhadap Pencapaian Akademik Siswa. Bandung: Universitas Pendidikan Indonesia.

Stuart and Sundeen. (1991). Principles and Pratice of Psychiatric Nursing. Ed.4. St Louis: The CV Mosby Year book.

Veeger, K. J. (2005). Realitas Sosial. Jakarta: PT. Gramedia Pustaka Utama.

Widagdo. (1993). Desain, Teori, dan Praktek. Seni Jurnal Pengetahuan dan Penciptaan Seni. BP ISI Yogyakarta III/03. 